\title{
Näktergalen mentorsverksamhet - möłen för växande
}

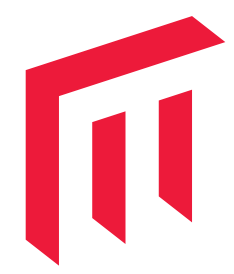




\section{Rapport}

(C) Copyright Lars Lagergren 2020

ISBN 978-91-7877-071-7

DOI 10.24834/9789178770717 


\section{LARS LAGERG REN NÄKTERG ALEN MENTO RSVERKSAMHET}

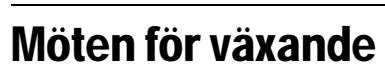

Malmö universitet, 2020

Lärande och Samhälle 
Publikationen finns även elektroniskt,

se diva.mau.se 


\section{INNEHÅLL}

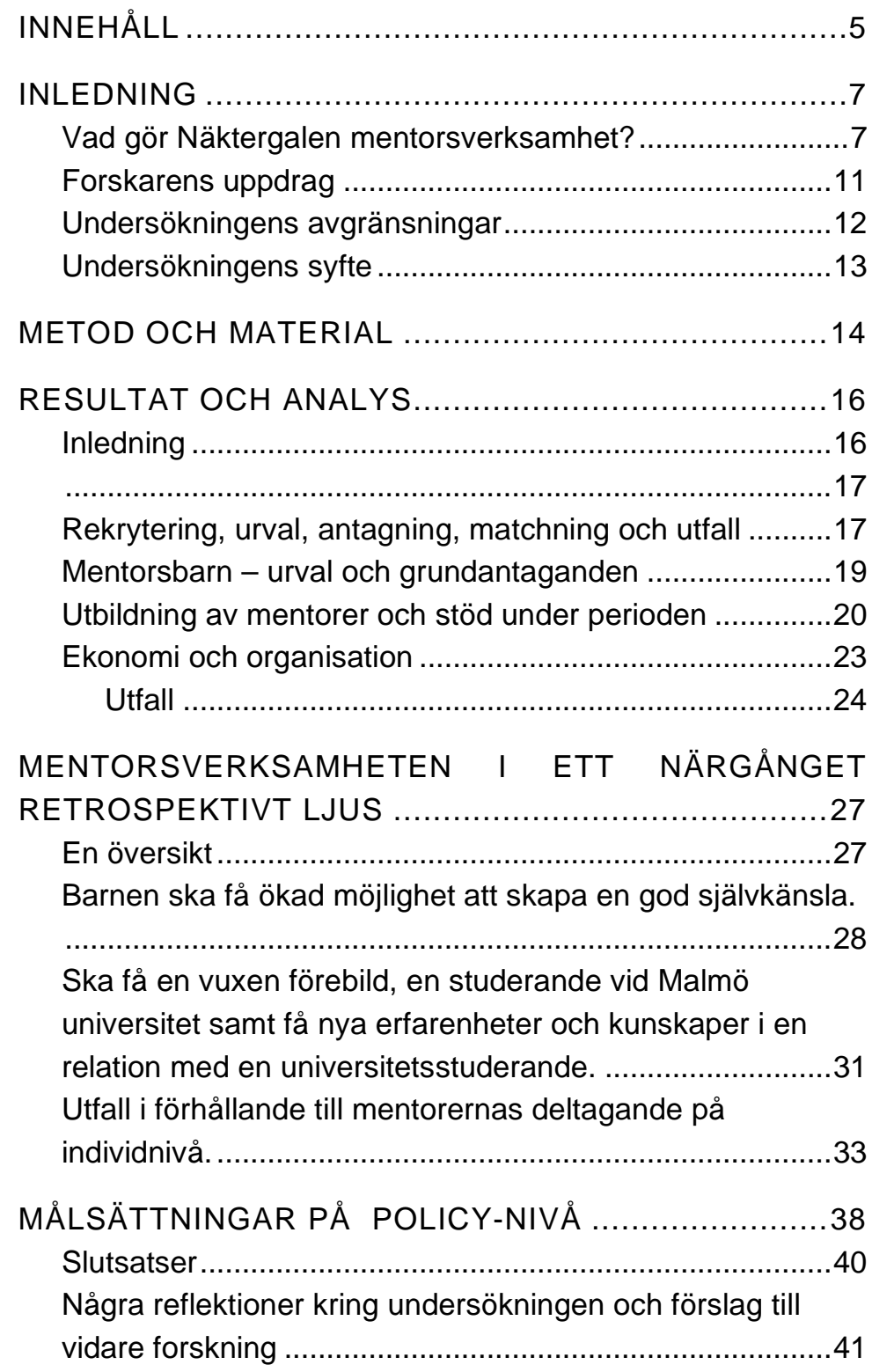


Litteratur......

43

Bilaga 1: Spridning av Näktergalen mentorsverksamhet.. 44 


\section{INLEDNING}

Näktergalen mentorsverksamhet har lika lång historia som Malmö högskola, numera Malmö universitet. Både startade sina respektive verksamheter runt 1996. De två är intimt förknippade med varandra. En viktig länk är högskolans/universitetets uppdrag att ta emot fler studenter från grupper som inte vanligtvis söker sig till högskoleutbildning och studenter med invandrarbakgrund än högskolor i allmänhet. Det gällde bl. a. studenter med svag studietradition; dvs. studenter från hem och regioner där det är mindre vanligt att gå vidare till högre utbildning. Näktergalen mentorsverksamhet är en av flera insatser som riktar sig mot just de grupper som vanligen är föremål för den breddade rekrytering som universitetet vill uppnå. I dag är Näktergalen mentorsverksamhet en fristående verksamhet inbäddad i- och till avgörande del finansierat av universitetet. En andra tung intressent är Malmö stad. Staden har varit involverade både aktivt och ekonomiskt. ${ }^{1}$ Den utvärdering som rapporten presenterar är genomförd på uppdrag av Malmö universitet. I utvärderingen (a.) analyseras och diskuteras deltagares minnen och erfarenheter liksom dokumentation producerad av verksamheten i relation till de syften och målsättningar som givits Näktergalen mentorsverksamhet genom åren.

\section{Vad gör Näktergalen mentorsverksamhet?}

Näktergalen mentorsverksamhet, till vardags förkortat till Näktergalen, har som grundtanke att dels vara till ömsesidig nytta för alla in

\footnotetext{
${ }^{1}$ Under de första åren samverkade Näktergalen med stadsdelen Fosie.
} 
blandade och dels att det ska leda till att nätverk skapas mellan barnen, deras familjer, deras skolor, studenterna och universitet. Själva verksamheten har således haft dubbla syften, ett för barnen och ett för mentorerna. $^{2}$

Verksamheten är helt frivillig. Både studenten och barnet ansöker om att få delta. En student som intervjuats, godkänts och utbildats matchas med ett barn som är i åldern 8 - 12 år och går på någon av Näktergalens fyra samarbetsskolor. De ska sedan träffas en gång i veckan, ca $2-3$ timmar per tillfälle, från oktober till en bit in i maj. De bestämmer själva vad de vill göra tillsammans. Barnets nyfikenhet, intressen och vilja utgör utgångspunkten för de gemensamma aktiviteterna och det är mentorns uppgift att försöka realisera dem. Näktergalen bjuder även på några gemensamma aktiviteter av olika slag.

En mentor erbjuds värdefulla erfarenheter, 3000 kr i lön för hela perioden, ett arbetsintyg samt utbildning och handledning. Barnet erbjuds möjligheten att få upptäcka och uppleva nya saker och aktiviteter samt att en gång i veckan under perioden få ha en vuxen person alldeles för sig själv. Det hela låter som ett fantastiskt erbjudande både för studenten och för barnet. En genialt enkel idé som erbjuder något positivt för alla inblandade. Hur bra denna mentorsverksamhet än låter finns där anledning att studera den närmare, för det enkla är ofta även det svåra. Varför finns den inte allmänt spridd vid universitet runt om i Sverige? Vad är det som hindrar? Eller om vi vänder på frågan, varför har verksamheten varit så stadig i Malmö och vid dess forna högskola och nuvarande universitet? Eller har den varit så stadig? Hur kommer det sig att idén och verksamheten spridits vidare från Malmö till ett drygt 20-tal universitet runt om i Europa och i Ghana?

För att få en tydligare bild av Näktergalen mentorsverksamhet kan vi studera dess syften och målsättningar över tid. Dessa syften och målsättningar ger oss också en bild av vilka avgränsningar som finns. Under åren 1997 - 2015 formulerades verksamhetens syften enligt följande:

2 Sild Lönroth, Carina (2007) Näktergalen - en knuff framåt; Rapporter om utbildning; Lärarutbildningen, Malmö högskola, 2/2007. S. 16. Jag har genomgående uppdaterat "högskolan” till dagens "universitet”. 


\section{Barnen}

- Ska få ökad möjlighet att skapa en god självkänsla.

- Ska få en vuxen förebild, en studerande vid Malmö högskola.

- Ska få nya erfarenheter och kunskaper i en relation med en universitetsstuderande.

\section{Mentorerna}

- $\quad$ Ska få möjlighet att vara en vuxen förebild i en nära relation med ett barn.

- Ska få en inblick i ett barns liv och härigenom ökad kunskap, förståelse och empati för människor olika villkor.

- Ska få ett komplement till sin universitetsutbildning, ”kunskaper man inte kan läsa sig till”. 3

Samtliga syften riktar sig mot att deltagarna ska ges chansen till personlig utveckling. Något utöver det som skola, familj och högskola kan ge. Något som både förgyller vardagen och stärker framtiden för deltagarna.

En verksamhets syfte(n) kompletteras ofta med mer konkreta målsättningar. För Näktergalen mentorsverksamhet formulerades tre sådana målsättningar till verksamhetsåret 2015/16:

- $\quad$ Målet är att vänskapen mellan barn och mentor ska leda till en ökad förståelse, respekt och tolerans för varandras olika sociala och kulturella bakgrunder.

- Målet är att barnen ska klara sig bättre i och utanför skolan och högre utsträckning söka till högskolestudier.

- Målet är att mentorerna genom sitt mentorskap långsiktigt ska motverka snedrekryteringen på högskolor och universitet, och därigenom bidra till en utjämning av sociala och utbildningsmässiga skillnader.

Nu har siktet ändrats i två av tre målsättningar. Mentorsverksamheten ska gynna Malmö högskolas framtida rekrytering av studenter samt lösa sociala orättvisor. Målen reviderades åter till nästkommande verksamhetsåret, 2016/17 till de mål som gäller när detta skrivs (december 2019):

- $\quad$ Bidra till breddad rekrytering och inkludering vid Malmö universitet.

\footnotetext{
${ }^{3}$ Sild Lönroth, Carina (2007), s.17.
} 
- Bidra till ömsesidigt utbyte och integration i Malmö stad.

- Bidra till skolelevers och universitetsstudenters utveckling och lärande.

De individrelaterade formuleringarna är nu i det närmaste helt borta. $\mathrm{Nu}$ ska mentorsverksamheten "bidra” till att uppfylla generella målsättningar uppsatta utefter, som det verkar, övergripande policys för Malmö universitet. Malmö stad, å sin sida, har hållit fast vid samma uppdragsbeskrivning:

Ömsesidigt utbyte mellan elever i Malmö stads grundskolor och studenter vid Malmö universitet. Att skapa goda relationer mellan studenter och barn i syfte att entusiasmera till framtida studier, ge möjligheter för eleverna att se och uppleva Malmö ur olika perspektiv och erbjuda meningsfull fritid. Studenterna är positiva förebilder och kan ge barnen samtalsstöd. Näktergalen fyller en social funktion för nyanlända barn och familjer som via sin mentor kan utvidga sitt kontaktnät stimulera språket samtidigt som mentorerna får möjlighet att lära känna våra "nya svenskar". ${ }^{4}$

Målsättningarna för det uppdrag Malmö Stad ger verksamheten skiljer sig i sak från Malmö universitets. Här betonas dock ”nya svenskar” som målgrupp.

Dokumentationen visar också på en tydlig avgränsning av målgruppen. En avgränsning som tycks ha varit underförstådd och i realiteten funnits hela tiden. Från början och fram till 2013 var det stadsdelen Fosie som medfinansierade mentorsverksamheten. Därefter har Malmös stads grundskoleförvaltning gått in med årliga medel. Två av de "fasta” skolorna som ingått i mentorsprogrammet ligger i delar av Fosie som beskrivs som segregerade ${ }^{5}$, vilket talar för att målgruppen redan från början varit barn som växer upp och går i skolan i s.k. utsatta områden.

Det lokala uppdraget för Näktergalens mentorsverksamhet har gått från att vara direkt riktat mot vad verksamheten förväntas ge sina deltagare, till att i generella termer beskriva vad mentorsverksamheten ska bidra till

\footnotetext{
${ }^{4}$ Avtal avseende Näktergalen mentorverksamhet.

${ }^{5}$ Stigendal, Mikael (1997) FOSIE - Sociala värden i olika sociala världar; Delrapport 3 Levnadsundersökningen; Malmö hus museer, Malmö.
} 
för att stärka och diversifiera universitetets studentunderlag och stadens ansträngningar att minska segregationen samt öppna upp stadens möjligheter för fler av dess innevånare. De olika sätten att formulera uppdraget på går inte stick i stäv med varandra, men de ger en bild av en förflyttning från det unika till en direkt policy-anpassad syn på verksamheten.

Denna studie ämnar i första hand granska det unika, det som sker i verksamheten och vad, om något, den inneburit för deltagande barn och mentorer samt vad den kan tänkas bidra med. I andra hand kommer förutsättningarna för att bedriva verksamheten att granskas och diskuteras.

\section{Forskarens uppdrag}

Sommaren 2017 lyste fakulteten för Lärande och samhälle ut medel för följeforskning på Näktergalens mentorsverksamhet. ${ }^{6}$ Själva forskningsinsatsen inleddes först runt årsskiftet 2018/19, då jag, docent Lars Lagergren, åtog mig uppdraget. Formuleringen av uppdragets forskningsdel var oförändrad:

Forskningsresultaten förväntas bidra med ny kunskap som synliggör programmets betydelse för de involverade individerna, inte minst när det gäller lärande och identitet. Forskningen ska på ett tydligt sätt adressera social bakgrund, utbildning, genus, etnicitet, generation och/eller andra kritiska perspektiv och vara kopplad till lärandeprocesser i vid mening. Genom att ta del av olika aktörers erfarenheter till exempel mentorernas, barnens, föräldrars/vårdnadshavares, programansvarigas, inblandade skolors och andra aktörers (t.ex. kultur-, fritidsverksamheter) och deras representanters - förväntas forskningen bidra till en fördjupad förståelse för sociala relationer, lärande, identitetsskapande processer och eller historiska processer som sker eller har skett inom ramen för Näktergalen. ${ }^{7}$

Min tolkning av uppdraget är att det gavs en bred ansats, med möjligheter till avgränsande fördjupningar. En tolkning som rimmar med uppdragets

\footnotetext{
${ }^{6}$ Beslut om tilldelning av medel (2017-06-27) Malmö högskola, Fakultetens för lärande och samhälle, Dnr; STUD 3.5.3-2017/1102

${ }^{7}$ Johnsson, Christina (2017-11-05) Utlysning: Medel för förstudie om forskning om Näktergalen; Fakultetens för Lärande och Samhälle, Malmö högskola.
} 
andra del, som riktade sig mot att författa en ansökan om forskningsmedel för en fördjupad undersökning. Den undersökning som skulle genomföras ska alltså dels resultera i en rapport/artikel och dels utgöra underlag för en forskningsansökan.

\section{Undersökningens avgränsningar}

Efter samtal med uppdragsgivaren gjordes ett antal avgränsningar och fördjupningar av uppdraget. Den forskarinsats som ligger till grund för denna rapport har utifrån nyss nämnda förutsättningar och i samförstånd med uppdragsgivaren kommit att bli utvärderande karaktär, utan några teoretiserande fördjupningar innehållande både en studie över tid av verksamheten fram till nu och en studie av verksamheten i nutid. ${ }^{8}$ Båda studierna beskrivs i denna rapporten.

De metodologiska valen för båda studierna måste anpassas till de förutsättningar som erbjuds dels utifrån verksamhetens grundtankar, syften och målsättningar och dels utifrån de aktuella tidsaspekterna - tidsramen för undersökningens genomförande och genomförandetidens förhållande till pågående verksamhet. Själva mentorsverksamheten pågår med början under höstterminen och åtta månader framåt. Detta omöjliggjorde att löpande följa en "verksamhetscykel", vilket hade varit att föredra. Till de tidsrelaterade problemen kan adderas att den närhet som en sådan ansats innebär, enligt vår ${ }^{9}$ bedömning, krävde en etikprövning även om alla nödvändiga skriftliga godkännanden från alla inblandade barn, föräldrar och mentorer kunnat samlas in. En etikprövning skulle även omfatta möjligheten att ta del av rapporter författade av mentorer, etc. Med dessa begränsningar i åtanke kom undersökningsmaterialet som beskrev den innevarande perioden att bestå i intervjuer med mentorer och verksamhetsansvarig samt "anonymiserat" material i form av data och sammanställningar av olika slag. Fokus förflyttades därmed i retrospektiv riktning. Ur ett "kvantitativt" forskningsperspektiv kan de grundtankar, syften och målsättningar som ska styra Näktergalen mentorsverksamhet utgöra en utmaning. Det finns få möjligheter att omvandla dem till något mätbart; det vill säga, om syften och mål har uppfyllts och i så fall i vilken mån de

${ }^{8}$ Den av ekonomiska och personella ramen för själva undersökningen var ca 15\% av tjänst under 2019

${ }^{9}$ Forskaren, verksamhetsansvarig och koordinator. 
gjort det. Näktergalen mentorsverksamhet är helt enkelt inte en verksamhet formad av new-public-managements principer om mätbarhet. ${ }^{10}$ Det finns heller ingen uppenbar kontrollgrupp att ställa resultaten mot eller en mall mot vilken vi kan avgöra om t.ex. antalet mentorsbarn som påbörjat akademiska studier kan bedömas vara högt, tillräckligt eller kanske otillräckligt. De enda jämförelser som går att göra är lokaliserade inom verksamheten, t.ex. jämförelser över tid.

Näktergalen mentorsverksamhet har genom åren varit expansiv. Modellen har exporterats till nya universitets-/högskolekommuner inom Sverige och internationellt, liksom till andra grupper av deltagare. Den undersökning som ligger till grund för denna rapport har emellertid fokuserat på den lokala verksamheten i Malmö med barn och studenter.

\section{Undersökningens syfte}

Näktergalens mentorsverksamhet är varken ett projekt eller en verksamhet som kan liknas vid ett modelltåg som tuffar runt en bana varv efter varv. Verksamheten har en utåtriktad och expansiv sida. Dock finns det en tydlig kärna i själva mentorsverksamheten. Undersökningen kommer att fokusera på denna kärna lokalt för Malmö. Den utåtriktade verksamheten behandlas endast summariskt.

Syftet med undersökningen är att förstå och diskutera om, och i så fall, hur, Näktergalen mentorsverksamhet i sin kärnverksamhet möter de uppsatta målen ur både ett deltagar- och verksamhetsperspektiv. Med "förstå" menas att beskriva, förklara och se konsekvenserna av, i detta fall, Näktergalen mentorsverksamhet på individnivå för att utifrån denna förståelse diskutera verksamhetens bidrag på policy-nivå.

${ }^{10}$ Om "new-public-management och mätbarhet, se t.ex.: Lagergren, Lars \& Book, Karin (2019) ”Projektifiering - Fokus idrott och integration" Ur: Sport management II - Den svenska idrottens styrning; SISU Förlag 


\section{METOD OCH MATERIAL}

Näktergalen mentorsverksamhet är väl dokumenterad. Det skriftliga material jag tagit del av för undersökningen är av olika slag. (1.) Två monografier skrivna under verksamhetens första tio år. Den första var en utvärdering av de första åren, 1997 - 2000 då verksamheten bedrevs som projekt finansierat av Wallenbergstiftelsen, författad av Lena Rubenstein Reich (2001) ${ }^{11}$. År 2007 kom den andra monografin Näktergalen - en knuff framåt som författats av verksamhetsansvarige Carina Sild Lönroth. ${ }^{12}$ Båda monografierna beskriver ingående verksamheten samt dess idégrund och utfall under de aktuella perioderna. En (2.) kombinerad Verksamhetsberättelse och bokslut för varje verksamhetsår 2007 - 2019. Dessa skrifter ger en god översikt över respektive verksamhetsår. Till ovanstående kommer (3.) dokument av olika slag som tillhandahållits av Näktergalen mentorsverksamhet.

Den här undersökningen huvudsakliga material består i intervjuer genomförda individuellt eller i par, både öga mot öga eller per telefon. Till dessa kommer fokusgruppintervjuer samt skrivna berättelser:

\begin{tabular}{|l|r|}
\hline Insamlingsteknik & $\begin{array}{l}\text { Antal informan- } \\
\text { ter* }\end{array}$ \\
\hline Intervjuer & 21 \\
\hline Fokusgrupp & \multicolumn{2}{|c|}{14} \\
\hline Telefonintervjuer & 15 \\
\hline Skriftligt via mail & 10 \\
\hline Antal mentorsbarn & \multicolumn{2}{|c|}{36} \\
\hline Antal Mentorer & \multicolumn{2}{|c|}{27} \\
\hline
\end{tabular}

*5 informanter har varit både mentorer och mentorsbarn.

${ }^{11}$ Rubenstein Reich, Lena (2001) Mentorsprojektet Näktergalen. Mötet mellan skolbarn och högskolestudenter; Malmö Högskola, Lärarutbildningen, Regionalt utvecklingscentrum; Rapporter om utbildning 4/2001, Malmö.

${ }^{12}$ Slid Lönroth, Carina (2007). 
Informanterna har "fångats” på olika sätt, men främst genom utskick gjorda av verksamhetsansvarig. Andra har hört av sig själva eller uppmärksammats av kollegor till forskaren eller genom att informanten fått information om undersökningen på annat sätt, till exempel genom bekanta.

Urvalet har gjorts med utgångspunkt från undersökningens inriktning mot idag vuxna före detta mentorsbarn. Det vill säga att de befinner sig i åldrarna 19 år och uppåt och de var mentorsbarn någon gång mellan åren 1997 - 2012. Mentorernas period som aktiva är vidare och ligger i regel senare, ungefär mellan $2002-2019$.

Intervjuer och fokusgruppssamtal spelades in, medan skriftliga noteringar gjordes vid telefonintervjuerna. Längden på intervjuerna var i båda fallen mellan 14 minuter som kortast till ca 90 minuter (fokusgrupp). Intervjuerna var inte standardiserade, utan syftade till att inledningsvis väcka informantens minnen genom riktade frågor om händelser och förutsättningar. Därefter, med utgångspunkt från vad som framkommit fördjupa och bredda för att få fram mer sammanhängande berättelser och fler minnen. Slutligen ställdes frågor i syfte att låta informanten reflektera över sitt mentorskap/tid som mentorsbarn och vilken eventuell betydelse de gjorda erfarenheterna haft både då och senare. Vid par-intervjuer och fokusgruppssamtal gavs även möjligheter till jämförelser.

De skriftliga berättelserna har varit insända av både före detta mentorer och före detta mentorsbarn, vilka fått utskicket, men inte kunnat delta för en intervju eller fokusgrupp. Dessa berättelser varierade från en halv A4sida till 4-5 sidor.

En majoritet av informanterna har varit kvinnor. Vilket speglar fördelningen bland både mentorer och mentorsbarn sett ut genom åren. 


\section{RESULTAT OCH ANALYS}

\section{Inledning ${ }^{13}$}

Med medel från Wallenbergstiftelsen startades Näktergalen som ett pilotprojekt 1996 vid dåvarande Lärarhögskolan. Verksamheten har sedan dess pågått utan avbrott och i skrivande stund genomförs den 23:e säsongen. Under denna tid har mycket hänt. Verksamheten har slipats och utvecklats, men också anpassats till varierande ekonomiska förutsättning och studentunderlag. Under de första åren gick man endast ut med information till Lärarutbildningen studenter. Därefter har verksamheten riktat sig mot studenter vid högskolan/universitetets samtliga fakulteter för att locka mentorer. De ekonomiska förutsättningarna har varierat genom åren ofta beroende på om verksamheten kunnat fånga externa medel eller inte. Som exempel har den ersättning/lön som studenterna erhållit för genomfört mentorskap har i reda pengar halverats från starten till idag - från $6000 \mathrm{kr}$ till $3000 \mathrm{kr}$.

Vid genomgång av budget- och ekonomisk redovisning för ett antal år framgår att verksamheten år för år agerat för att både säkra, anpassa och utveckla sin verksamhet. När det gäller förutsättningarna för driften av verksamheten har dessa således aldrig varit helt stabila. Däremot har själva driften, dess utgångspunkter och genomförande, varit stabil. Här har förändringsarbetet i allt väsentligt varit inriktat på finslipning och förbättringar av grunderna för mentorsverksamheten.

\footnotetext{
${ }^{13}$ Inledningen bygger på samlade uppgifter från intervjuer med verksamhetsansvarig, informationsskrifter och nätsidor publicerade av Malmö universitet, Malmö stad och Näktergalens mentorsverksamhet samt dokument framtagna av ansvarig ekonom vid Fakulteten för lärande och samhälle.
} 


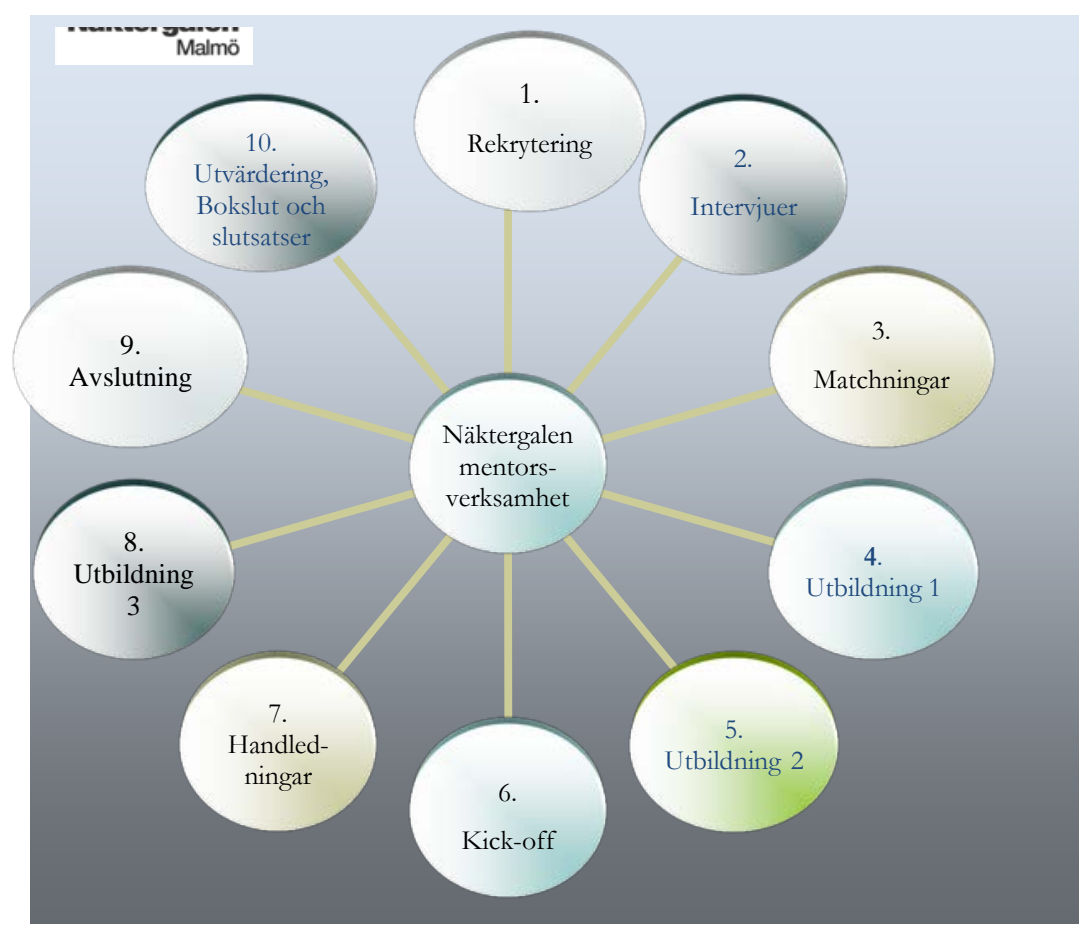

\section{Rekrytering, urval, antagning, matchning och utfall}

Att matcha samman två människor som i grunden kanske inte har annat gemensamt än att de för tillfället bor i Malmö och sedan skapa förutsättningar för att de två ska umgås en gång i veckan under åtta månader är inget lätt åtagande. Näktergalen mentorsverksamhet löser detta åtagande på ett genomtänkt och metodiskt sätt. Verksamhetens aktiviteter är uppdelad i 10 faser enligt figuren ovan.

Personliga förutsättningar och förväntningar från båda håll ska fångas och läggas till grund för matchning. Ett grannlaga arbete då det kan röra sig om mellan 80 och 120 barn samt 120 och 160 mentorer som anmält sig varje år. ${ }^{14}$ Rutiner och tydlighet är således mycket viktiga, vilket också

${ }^{14}$ Antalen är hämtade ur Verksamhetsberättelser och bokslut för åren 2009/10 till och med 2018/19. 
poängteras vid samtal med ansvariga. Enligt forskning finns det en del nyckelfaktorer i mentorsprogram som visat sig ha avgörande betydelse för att goda relationer mellan mentorer och barn ska utvecklas. Dessa nyckelfaktorer är rekrytering, urval, intervjuer och kontroll av sökande samt utbildning, stöd och handledning. ${ }^{15}$ Utvärderingar av avknoppningar från verksamheten i Malmö visar även på nyckelfaktorernas betydelse:

Kärnan i mentorsprojektet är förvisso relationen mellan mentor och barn. Men vore det inte för stödstrukturerna och hur dessa omsätts av projektledningen hade vi inte haft den goda genomströmning och kvalitativa goda resultat som utvärderingarna visar på. ${ }^{16}$

Nattergalen menar att strukturen och ramarna varit mycket viktiga för implementeringen av Nattergalen. ${ }^{17}$

Rekryteringsmetoderna för att locka mentorer inför perioden 2018/19 skedde via skriven information/affischering, muntlig information vid upprop/introdagen och klassinformation samt via sociala medier. ${ }^{18}$ Skriven information/affischering fångade $57 \%$ av sökande, därefter kom klassinformation (19\%). Rekryteringen genomfördes på fem fakulteter. Flest sökande återfanns på Lärande och samhälle (55) följt av Kultur och samhälle (44). Fördelningen av de 64 studenter som efter intervju blev antagna som mentorer speglade denna fördelning. -Kvinnor utgör en tydlig majoritet av båda sökande och de som blir antagna.

Motsvarande siffror för barnen var 101 anmälda vid de fyra skolorna, av vilka 64 matchades fram efter att ha deltagit vid informationsmöte och tillsammans med vårdnadshavare intervjuats. ${ }^{19}$ Fler flickor (43) än pojkar (21) blev antagna. Varje enskild skola har sin egen urvalsprocess och denna kan, till skillnad mot processen för mentorer vid Mau, variera.

\footnotetext{
${ }^{15}$ David Du Bois, Nelson Portillo, Jean E Rhodes. Naida Silverthorn and Jefferey C Valentine. (2011) How Effective Are Mentoring Programs for youth? A Systematic Assessment of the Evidence; Psychological Science in the Public Interest; 12(2) 57-91

${ }^{16}$ Henrik Nilsson (2013) Tre år med Näktergalsprojektet $i$ Växjö. Växjö:Linnéuniversitetet

${ }^{17}$ Elisabeth Backe-Hansen, Marie-Louise Seeberg, Anne Solberg, Elsiv Bakketeig \& Joshua Patras (2011), Gjensidig trivsel, glede og læring. Evaluering av mentorordningen "Nattergalen"; NOVA, 2011, Rapport 26/11

${ }^{18}$ Innehållet i detta avsnitt utgår från två källor dels intervjuer med verksamhetsansvarig Carina Sild Lönroth och dels från Verksamhetsberättelser och bokslut från åren 2009/10 till och med 2018/19. Jämförelser utgår från den senare.

${ }^{19}$ Vårdnadshavare har rätt att komplettera barnens utsagor vid intervju.
} 


\section{Mentorsbarn - urval och grundantaganden}

Mentorsbarnen väljs ut av respektive skola. Proceduren ser lite olika ut, liksom vilka utses till kontaktpersoner. Under senare tid är det fyra skolor per år som deltar. Grunderna för urvalet är behov och möjlighet. Verksamhetsansvarig beskriver det i färgerna grön, gul och röd. "Grön”, utgör barn som egentligen inte bedöms vara i behov av en mentor, medan "röd" utgörs av barn som upplevs ha så stora sociala problem att de riskerar att bli överväldigande för en mentor att hantera. Målgruppen befinner sig inom den "gula" sfären, barn som av skolan bedöms ha det lite tufft eller har svårt att passa in riktigt. Dessa problem kan t.ex. röra språk, blyghet eller koncentrationssvårigheter. Sannolikt har det varit en överrepresentation av barn med många syskon, vilka tenderar att försvinna och ensambarn, som har det tufft att passa in.

Det finns en uppenbart inkluderande/integrerande tanke bakom verksamheten. De skolor som väljs ut har sina upptagningsområden vars populationer utmärks av hög andel innevånare med "utländsk bakgrund", låg sysselsättningsgrad och låg medelinkomst. Socioekonomiskt index ${ }^{20}$ för de skolor som ingick 2017/18-års verksamhet låg mellan 220 och 290, vilket placerar dem bland de 15 grundskolor med högst index, dvs. bedöms vara i störst behov av ekonomiskt stöd för att uppnå läroplanens mål, av Malmös 75-talet grundskolor. Skolorna ligger i vad Salonen, Grander \& Rasmusson beskriver som segregerade områden. ${ }^{21}$

Föräldrarnas aktiva närvaro är avgörande i urvalsprocessen. Som vårdnadshavare ska de godkänna att barnet får delta och finnas med barnet vid informationstillfället för att barnet ska matchas med en mentor. Förälder ska närvara vid det första mötet mellan mentor och barnet.

\footnotetext{
${ }^{20}$ Variabler som sammantaget bestämmer en skolas index i Malmö är: Kön, Nyligen invandrad, Högsta utbildning för vårdnadshavarna, Ekonomiskt bistånd, Bor med en eller båda vårdnadshavarna, Skolans sociala tyngd, Bostadsområdets sociala tyngd.

${ }^{21}$, T, Grander, M \& Rasmusson, M, (2019) Segregation och segmentering i Malmö: Stadskontoret, Malmö Stad
} 


\section{Utbildning av mentorer och stöd under perioden}

En mentor erbjuds tre utbildningstillfällen; ett inför mentorsperioden, en utbildningskväll på barnets skola och ett i mars månad inför separationstillfället. Mentorn erbjuds individuell handledning vid två tillfällen plus ett handledningstillfälle tillsammans med mentorsbarnet. Därtill erbjuds reflektionsstöd via frågor i månadsdokumentationerna. Dessutom står det en mentor fritt att uppsöka Näktergalens bemannade kontor för frågor. Stor vikt läggs vid mentorns egen lärandeprocess. De ska förberedas på vad som komma skall och hur att skapa goda relationer.

Upplägget för de tre utbildningstillfällena är från början hämtat från föregångaren, den israeliska mentorsverksamheten Perach ${ }^{22}$, vilket sedan har anpassats och modifierats vidare. Allt utvecklingsarbete utgår från samma fråga "Vad är det mentorerna behöver?”. Verksamhetsansvarig Carina Sild Lönroth utvecklar:

De behöver ju framför allt veta hur det är att vara mentor, vad skiljer mentorsrollen från lärarrollen, eller föräldrarollen eller bästa-vän-rollen. (...) Forskning visar på betydelsen av att förbereda mentorerna för sitt uppdrag (...) deras self-efficacy ${ }^{23}$ för att de ska kunna klara sitt uppdrag har betydelse. De med god self-efficacy klarar uppdraget bättre, kan fullfölja det också och har lättare att skapa goda relationer. $^{24}$

Det första samlade utbildningstillfället handlar om hur en god relation skapas. De olika stadierna i relationen; från en inledande osäkerhet inför varandra till ett moget mentorskap, att bli testad av barnet och att avsluta. Här lyfts också vikten av att fokus ska ligga på vad barnet kan, som barnet tycker om att göra, att göra aktiviteter och det inte handlar om läxhjälp, utan ”växhjälp”, som Carina uttrycker det. Ledorden är; lek mycket med

\footnotetext{
${ }^{22}$ För vidare information rörande Perach, se t.ex.: http://www.perach.org.il/The-Perach-Tutorial-Project

${ }^{23}$ Begreppet "self-efficacy" kan enkelt definieras som; en människas tro på att hon har de kunskaper o och förmågor som krävs för att hon ska kunna utföra den uppgift som ligger framför henne. Ursprung; Bandura, A. (1977). Self-efficacy: Toward a unifying theory of behavioral change. Psycho-logical Review, 84, 191-215. Bandura, A. (1986). Social foundations of thought and action: A social cognitive theory. Englewoods Cliffs, NJ: Prentice Hall.

${ }^{24}$ Intervju med verksamhetsansvarig Carina Sild Lönroth 2019-11-25. Samtliga citat i detta avsnitt hämtas från intervjuer eller samtal med Carina om inte annat anges.
} 
barnen och ha kul tillsammans! Upptäck Malmö genom dess möjligheter. Låt barnet komma till många platser och göra olika saker. Ha det kul själv. Både direkt och indirekt behandlar utbildningstillfället mentorsuppdragets avgränsningar; från för uppdraget helt avgörande insikter, som att förstå att en mentor inte kan förändra ett barns uppväxt eller att en mentor kanske inte alltid kan förstå föräldrarna, men ska respektera dem. Utbildningen innehåller även rena direktiv, som att aldrig sova över hos barnet eller att vara mentor för barnets syskon.

På mentorns ansvar ligger att träffa barnet, samt hämta och lämna. Om barnet då inte är där? Carina beskriver ett exempel:

Ibland ringer de efter att ha stått där kanske tjugo minuter, ja då räcker det. Då får du försöka ta kontakt med dem i kväll, det kan ju ha varit ett missförstånd. Det är inte alls ovanligt.

De blivande mentorerna uppmanas att efter varje tillfälle fånga det positiva. Något som barnet sa eller gjorde. Något som går att ta fasta på till nästa gång och kanske därigenom ge idéer till nya aktiviteter. Det är vad en mentor ska lägga fokus på. Tillfället syftar också till att få mentorerna att känna att de tillhör en samlad grup, vilket förstärks av att före detta och aktiva mentorer berättar om sina erfarenheter från sina mentorskap. Dessutom går mentorskapet praktiska delar igenom, som t.ex. månadsrapporten. Slutligen får de blivande mentorerna barnens namn, ålder och skola. Ett viktigt moment i utbildningen är "vad det finns att göra i Malmö med barnet”.

Det första undervisningstillfället ger inte bara praktiska råd utan också en introduktion till de filosofiska grundantaganden som ligger till grund för mentorsverksamhetens praktik:

Kul att lyssna på föreläsningarna, som både finns inspelade och hålls regelbundet. Det här att det är genom mötet med andra människor som människan existerar. Det är den där praktiska moroten jag älskar. 
Efter första utbildningstillfället sänds ett brev till varje utvald familj. Där får föräldrarna reda på att en matchning har gjorts, medan barnet får reda på att de är välkomna till en startdag och vad mentorn heter. Det är viktigt, menar Carina, att det är samma förutsättningar för både barn och mentor; de möts utan att ha förutfattade meningar om varandra genom att de inte vet något om varandra.

Det andra utbildningstillfället sker på den skola barnet går. Tillfället är förlagt till samma vecka som de ska träffa barnet. En "kontaktperson” och ibland en rektor tar emot. Här ges information om skolans upptagningsområde och vad som finns att göra i området. Tillfället ger kontaktpersonen möjlighet att träffa alla mentorerna till barn som tillhör skolan. I särskilda fall kan kontaktpersonen ge en enskild mentor relevant information rörande barnet som kan vara av nytta, men då får det vara något mycket speciellt, understryker Carina. De blivande mentorerna får chans att bekanta sig med både miljö och ansvariga vid skolan. Fungerar mentorskapet väl kommer mentorn troligen inte ha någon vidare kontakt med kontaktpersonen.

Vid det tredje utbildningstillfället handlar det om att avsluta på ett tydligt och bra sätt. Tillfället är förlagt till första halvan av mars, ett par månader före perioden avslutas. Carina poängterar vikten av ett väl förberett avslut. Barnet ska förberedas om att det är ett begränsat antal tillfällen kvar och att studenterna måste prata med barnen om detta och de helst även ska prata med föräldrarna om det är så att människor kan komma i kläm här. Barnen får t.ex. inte uppfatta avslutet som ett svek från mentorns sida:

Nu säger vi åt studenterna att nu får ni tänka själva. Skulle ni vilja ha fortsatt kontakt efter vi har avslutat så är det upp till er, men vi vill att ni avslutar tydligt, vi har en avslutningsdag, ni säger "hej då” till barnet. Om ni sen träffas en gång i höst ska ni vara väldigt tydliga med det. Det här är inte längre Näktergalen med gemensamma aktiviteter. Gå inte in och förstör genom att säga ”Vi kan ju träffas ändå”, för det orkar ingen att träffas en gång i veckan hela livet. Mentorskapet ska inte vara en krycka, de har hittat nya aktiviteter, de kan gå iväg och säga Hej då. 
De ansvariga vill få mentorerna att tänka till - "vad vill jag egentligen?”. Deras roll är att försöka hjälpa i varje unik situation. Det kan vara mentorn som har problem eller känner sig osäker. Att hjälpa och stödja varje par, att finnas där och vara beredda hela tiden.

Obligatoriska handledningar ges tre gånger under perioden. Den första sker när mentorerna har träffats några gånger och den första månadsrapporten lämnats in och blivit läst. Förutom de tre obligatoriska tillfällena ges handledning efter behov och efterfrågan. Inget mentorspar går igenom hela perioden utan att ansvariga haft kontakt med dem. De ansvariga lägger även in aktiviteter.

Om ett mentorskap måste avbrytas, måste paret träffas en sista gång innan avbrottet sker. Det handlar i ungefär hälften av fallen inte om barnet, utan det är mentorn som inte kan fortsätta. Mentorn har då att se till att få till en trevlig avslutning. Här finns de ansvariga med och stöttar. Mentorerna berömmer handledarna (två koordinatorer och verksamhetsansvarig) tillgänglighet. Vilket tydligt framgår i de årliga enkätundersökningar som redovisas i Verksamhetsberättelserna/Boksluten, men även i några av intervjuerna:

Det var jätteskönt att jag kunde prata med koordinatorerna. Komma till insikten om att det finns andra sätt att ha en emotionell reaktion på. Erfarenheter som inte går att få tag på i styrdokumenten och det tycker jag är jättehärligt. Men det är en aktiv process - inte bara bli matad. Du måste själv satsa.

\section{Ekonomi och organisation}

Om vi räknar in alla insatser som de ansvariga - verksamhetsledare plus två koordinatorer - gör under ett år, från det att affischer sätts upp, genom urvalsprocess, matchning, utbildning, handledning och stöttning, insamlande, hantering och analys av månadsrapporter, förberedande av aktiviteter, summering av period, jaga externa finansiärer, m.m. - inser vi att det rör sig om ett drygt arbete. Om vi sedan beaktar att personalstyrkan som har att ansvara för en mentorsperiod idealt består av 2,0 tjänst; ansvarig ledare $75 \%$, koordinatorer $0,75 \%+50 \%$ av tjänst, blir den bilden 
än tydligare. Bemanningen har genom åren varierat, till som mest 6 tjänster. Antalet samvarierar delvis med antalet mentorspar. Med den 2,0 tjänst som nu har att driva verksamheten, kan antalet 60 - 70 mentorspar utgöra ett spann där den kan genomföras på ett tryggt och säkert sätt. Fler kräver sannolikt utökad bemanning.

I verksamhetsansvarigs tjänst ligger åtskilliga andra uppdrag och aktiviteter kopplade till bl.a. Näktergalen mentorskaps internationalisering, "fundraising", föreläsningar och uppstart av nya verksamheter.. Spridningen av Näktergalens verksamhetsmodell har varit betydande både nationellt och internationellt. Den har även överförts till andra målgrupper. Lista över spridningen, se Bilaga 1.

Näktergalen mentorsverssamhet är organisatoriskt placerad i institutionen Skolutveckling och ledarskap (SOL), Fakulteten för lärande och samhälle. Det har inte gått att utröna varför verksamheten placerats just där. Näktergalens och institutionens övriga verksamhet har inget uppenbart gemensamt. Sedan några månader är institutionens prefekt ytterst ansvarig för Näktergalen mentorsverksamhet, vilket inte varit fallet tidigare.

Om vi granskar Näktergalen mentorsverksamhets ekonomi ser vi fasta anslag om 2900 tkr från Malmö universitet per år ${ }^{25}$, samt 500 tkr från Malmö stad. ${ }^{26}$ Övriga eventuella intäkter är de som verksamheten drar in externt. Löner, LKP samt OH-kostnader och kostnader för lokaler och drift står för de stora kostnaderna. Mentorerna får $3000 \mathrm{kr}$ i arvode för sitt arbete. För verksamheter, det vill säga aktiviteter som inte är gratis för mentorer och mentorsbarn att ägna sig åt, budgeteras 50 tkr per verksamhetsår. Det innebär cirka 800 kr per par/period till aktiviteter.

\section{Utfall}

Under verksamhetens 22 genomförda säsonger har 1388 mentorspar fullföljt sina respektive mentorsperioder. Det ger ett snitt på 63 par per säsong, med en topp på 103 (2003/04) och 45 som lägst (2015/16).

${ }^{25}$ Summa gäller fr.o.m. 2017 och framåt. Summan har varierat genom åren.

${ }^{26}$ Anslag ges per kalenderår och inte per verksamhetsår. 
En mentorsverksamhet av det aktuella slaget innebär för studenten/mentorn ett stort ansvarstagande utanför studietiden under en tidsrymd av närmare två terminer. Mycket kan hända under denna tidsrymd, både för barnets och mentorns vidkommande. Det går inte att uppskatta hur stort antal matchningar som kan förväntas hålla hela perioden. Låt oss titta närmare på hur det har sett ut:

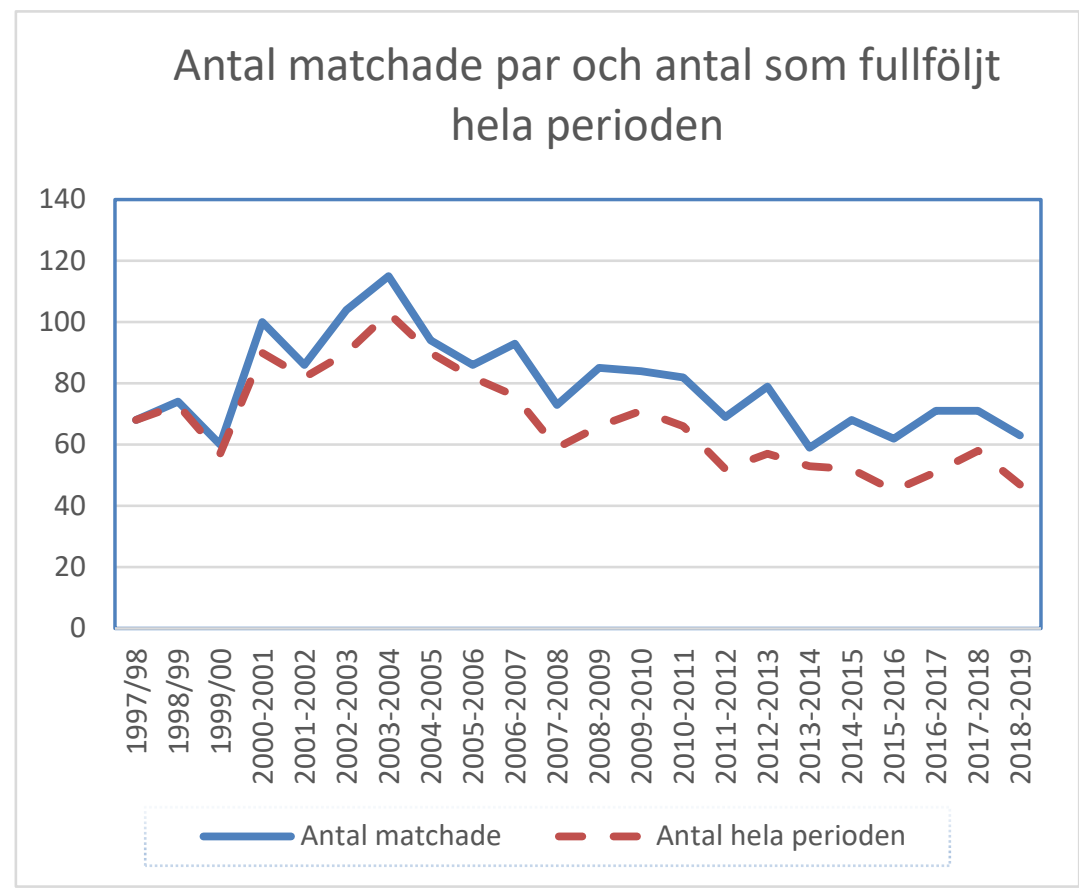

Diagram: Visar antalet matchade par och antalet par som fullföljde hela perioden från verksamhetens start 1997/98 till och med perioden 2018/19. Ur diagrammet går det också att utläsa differensen mellan antalet matchade par och antalet par som fullföljde perioden. Totalt över perioden fullföljde $85 \%$ av paren hela perioden. För de senaste 10 perioderna, 2009/10 - 2018/19 är siffran 78\%. Källa: Näktergalen mentorsverksamhet, Bokslutsrapporter för perioderna 2009/2010 2018/2019.

Avhopp är vanligast precis i början eller inför första tillfället samt efter nyåret. Det har varit ungefär lika många barn som mentorer som stått för avhoppen. Att i snitt 85\% av matchningarna för hela verksamhetstiden 
hållit måste, enligt mitt förmenande, ses som en mycket hög siffra, om vi väger in vad som kan hända två människor under en åttamånaders-period oberoende av deras deltagande i mentorsverksamheten. ${ }^{27}$ En stor andel, för vissa perioder mer än hälften, av avhoppen skedde redan innan första träffen. Just avhoppen är en del i verksamheten som ansvariga aktivt försöker att påverka genom olika justeringar av främst urvalsprocess och utbildning. ${ }^{28}$ En viktig faktor som lyfts av mentorerna är den handledning och det stöd som ges av koordinatorer och ansvarig (se exempel i citat ovan).

\footnotetext{
${ }^{27}$ Skäl bakom avhoppen var för perioden 2017/18: Barn; försvårade familjeförhållanden/familj kan inte stötta, barnet har för många egna aktiviteter, tappat intresse, kom ej till startdagen, flytt: Mentorerna; Sjukdom, studieavbrott, sjukdom i familjen samt ändrade familjeförhållanden. I de fall det varit ett gemensamt beslut att avsluta ett mentorskap; Mentor sjuk/ barnet ej motiverat, mamman har svårt att släppa taget om barnet/mentor sjukdom, mentor tidsbrist pga arbete efter förlorat CSN samt Både mentor och barn har svårt att mötas inom Näktergalens ramar: Verksamhetsberättelse/Bokslut nr 21, 2017/18, s. 24.

${ }^{28}$ Se, t.ex.: Bokslut år 16; Näktergalens mentorsverksamhet 2012/2013. Avhopp utgör en stående punkt i alla Bokslut som ingår i studiens underlag (2009 - 2019).
} 


\section{MENTORSVERKSAMHETEN I ETT NÄRGÅNGET RETROSPEKTIVT LJUS}

I detta avsnitt redovisas och diskuteras resultat från de intervjuer som genomförts samt de skrivna berättelser som kommit in från före detta mentorer och mentorsbarn. Urvalet har presenterats ovan i metodavsnittet.

\section{En översikt}

För att kunna få en uppfattning om hur Näktergalens mentorsverksamhet på individnivå möter verksamhetens syften och målsättningar har material insamlats genom intervjuer och i form av nedskrivna berättelser. I redovisning- och analys av det insamlade materialet utgår jag från dessa mål och syften.

Flera av de berättelser som utgör underlag för denna del rymmer många bottnar. Andra är enklare - i det närmaste oreflekterade minnen. Ett stort antal behandlar på ett djupare plan den situation barnet befann sig i vid den aktuella tiden. Några säger sig, så här långt senare, förstå varför just de blev utvalda. De var barn som inte mådde så bra eller inte riktigt "passade in". Det kunde handla om att de var blyga, retade eller kanske försvann bland sina syskon eller inte riktigt fick det stöd de behövde av dubbelarbetande föräldrar. De kunde också vara "hyperaktiva”, busiga och riskerade att hamna i socialt utanförskap. Urvalet av mentorsbarn tycks ha varit i stort sett enligt verksamhetens grundtanke. Jag återkommer till berättelser som beskriver när det inte fungerade.

I materialet framkommer några tydliga stråk. Ett är den positiva betydelse som en fungerande mentorsperiod haft, både för mentorer och mentorsbarn. De respektive betydelserna varierar i styrka och innehåll; från roliga minnen - ”Det är bara positiva minne som far upp i huvudet. Det är dom 
som etsar sig fast” - till att tillskriva mentorsperioden närmast livsavgörande betydelse:

Jag blev mer social. Vågade testa nya saker. Många minnen. Mycket betydelsefullt för mej. Än i dag betyder hon mycket för mig. Nästan så man vill spola tillbaka i tiden. Hon var en stjärna.

Lika tydlig är den besvikelse som präglar de ytterst fåtaliga (3 av 36) berättelserna om en dysfunktionell mentorsperiod. Två av dessa hänvisar till upplevt ointresse från mentorns sida, medan den tredje kan tolkas som utfall av en missad matchning.

Aktiviteterna upptar en stor del av de insamlade berättelserna. Här ryms nya upptäckter, som att gå på Operan och se en föreställning, Stadsbiblioteket, badhus, biljard, golf, fika med shopping på stan, eller liknande till aktiviteter som bakning, eller bara mys.

\section{Barnen ska få ökad möjlighet att skapa en god själv- känsla}

Det insamlade materialet ger många belägg för vikten av god en självkänsla och hur en mentor kan hjälpa till att skapa en sådan. Här ett axplock ur mentorsbarnens berättelser:

Jag var blyg från början, men det kändes bra. Hon var trevlig och gjorde mycket grejor. Hon var ju mycket äldre (...) Hon lärde sig mycket, vi blev vänner. Jag slutade att vara blyg. Det gav mej självförtroende.

Ett annat perspektiv som följt mig livet ut är att man känner sig annorlunda eller konstig när man är invandrare, speciellt mycket i vissa sammanhang till exempel i en grupp där ingen annan är som en själv. Som barn var detta en hemsk känsla men nu i vuxen ålder är jag stolt över min identitet som jag fötts i. Detta är nog bland det starkaste minnet jag fått nu när jag tänkt vad jag fått med mig av Åsa, att det var trevligt att träffa en svensk vuxen kvinna som spenderade tiden bara för mig. 
Se något annat, att kunna bygga upp sin självkänsla, att kunna umgås i andra sociala kretsar än den man är van vid. Det var givande. När jag tänker bakåt på mitt liv, så gav detta mig väldigt mycket. Ser jag på hur det var, så fastande vi i en och samma grej, det vara bra att jag fick chansen att komma bort, se något annat.

Skolan ordnade en mentor. Det lät kul. Vi hade precis kommit till Sverige. Hjälpte mig med språket. Sofie hette hon och studerade tandvård. Bio, träffa familj, sambo. Familjen tyckte om henne, efter vi varit ute umgicks vi med familjen. Sofie och jag blev tajta, en närmare relation. Vi pratade om mycket, jag var 9 år och Sofie 26. Jag gick förberedelseklass och höll på att lära mig språket. Hon hjälpte till med språket vi pratade bara svenska. Tänkt på henne, jag utvecklades som person. Troligen bara positivt. Kan tänka mej att vara mentor, vara en bra förebild, lära barnet nya saker och hjälpa till om något är svårt. Lära känna varandra.

Det gav mig en betydelse, hans bemötande gav mig mer mod - att kunna ta för sig. Det där att putta mig lite framåt, att våga uttrycka sig. Att inte bara vara vänner, att som barn kunna se in lite i det vuxna livet.

Flera berättelser rymmer liknande beskrivningar. I andra berättelser reflekterar de f.d. mentorsbarnen inte alls över hur de själva var eller om de på något sätt hade det svårt. Däremot lyfts detta med att bli tagen på allvar och lyssnad på:

Det jag gillade mest med henne var att hon var så intresserad av mej. Att hon faktiskt lyssnade på det man sa. Det var ju inte alltid så med vuxna, särskilt inte i skolsammanhang. Det är nog ganska vanligt som barn att man känner att vuxna lyssnar, men lyssnar inte egentligen, dom hör men lyssnar inte. Det är det viktigaste.

En positiv mentorsperiod behöver inte vara omvälvande eller leda till de djupa insikterna för att vara lyckad. Följande citat är sammansatt från en och samma berättelse: 
Det var jätteroligt och spännande. Vi hittade på saker. Kommer inte ihåg vad hon hette. Vi gick till olika lekplatser, var hos varandra, spelade kort, gick på museum. Blandade med egna idéer. Vi hade en kompisrelation, pratade mycket och hade kul. Viktigt att hon var vuxna, mer medveten om saker. Hon berättade om att hon var student. Jag vill själv vara mentor. Då skulle jag försöka komma nära, skapa kontakt, se till att vi har kul och hittar på saker tillsammans och lyssna. Bra att andra får uppleva detta.

Bland berättelserna ryms också ett exempel som skiljer helt sig från övriga. Exemplet nedan visar på när den gula signalen hade övergått till rött rörande den sociala situationen för barnet och dess familj:

Jag gjorde dumma saker som barn. Fick sitta av tiden i skolan. Vi var sfem stycken i ett rum. Blev utslängd till slut. Ville komma bort från familjen och skolan. Mentorn var en tjej. Hon var mycket naiv. Jag mötte henne alltid utanför porten. Vi hittade på saker tillsammans ville se nya ställen och komma bort. Det hjälpte inte. (Utdrag ur författarens noteringar från telefonintervju)

Min tolkning här är att barnets situation var så problematisk att den översteg vad en mentor kan eller ska hantera. En mentor ska erbjuda glädje, nya upptäckter och insikter. Min tolkning är vidare, att mentorn i detta fall utförde sitt uppdrag, kanske helt omedveten om barnets sociala situation och psykologiska tillstånd. Därav den naivitet barnet tillskriver henne. Exemplet pekar även på mentorsuppdragets dubbelhet, dels att ge något positivt i stunden och dels att ge ett bidrag för framtid. I det förra exemplet fångade mentorsbarnet aktivt stunderna med mentorn. Några berättelser visar på motsatsen, när mentorsbarnet är mer av en passiv mottagare av vad mentorn kan ge:

Jag har inte många minnen från min barndom. Mycket av det blev överskuggat av mina föräldrars skilsmässa och att passa in i skolan. Många av mina minnen från barndomen är suddiga. Men jag kommer ihåg en tjej som jag träffade som heter Malin. Hon var snäll och trevlig och jag hade jätte roligt när jag träffade henne. Men jag kommer inte ihåg vad vi gjorde, förutom en gång då vi spelade bowling. Som barn 
var jag jätte tystlåten och blyg. Vi pratade inte särskilt mycket men när jag fick reda på att jag inte skulle träffa henne mer så blev jag ledsen. Jag önskade att jag hade fått mer tid med henne. Kanske hade det blivit lättare för min barndom då. Så att jag hade vågat öppna upp.

(Berättelse insänt per mail)

De insamlade berättelserna från f.d. mentorsbarn visar på flera avgörande faktorer som påverkar om deltagandet kan ge en positiv inverkan på barnets självkänsla. Barnets sociala och psykologiska förutsättningar att tillgodogöra sig det en mentor kan ge samt mentorns förmåga att nå fram till barnet. Mycket faller tillbaka på ett fungerande urval och en precis matchning, men handledning av mentorerna och andra stödinsatser har också direkt inverkan. Under den kommande rubriken slås de två återstående delsyftena samman.

\section{Ska få en vuxen förebild, en studerande vid Malmö universitet samt få nya erfarenheter och kunskaper $\mathrm{i}$ en relation med en universitetsstuderande}

Detta första syfte kan delas upp i två delar; mentorn som vuxen förebild generellt och mentorn som en förebildspecifikt som en student vid Malmö universitet. Vad som menas i det senare fallet är inte helt tydligt. Nedanstående citat borde passa in:

Jag kommer ihåg att när vi var i den här byggnaden (Orkanen, där Lärarutbildningarna huserar, min anm.), så kommer jag ihåg att det var jättekul för att hon kunde öppna dörrar och här kunde vi vara och göra saker. Det kändes som någon sorts frihet man kunde ha, fina miljöer. Hon verkade trivas på sin utbildning. För mej så var det ganska influerat av att hon var student. Jag tycker absolut att jag fick en inblick i det. (...) Ingen av mina föräldrar har studerat, bara grundskola.

Citatet är kanske det tydligaste, där förebildens positiva koppling till Malmö universitet lyfts fram, vilket egentligen borde kopplas till det andra av de två syftena. Andra citat är mindre detaljerade:

Visste att hon var en student och vi besökte också högskolan. Min plan är också att jag ska läsa på högskola. 
En majoritet av de f.d. mentorsbarnen säger sig ha varit medvetna om att mentorn var student och att de besökt universitet tillsammans med mentorn. Andelen som sedan själva studerat vid Malmö universitet/högskola är svår att fastställa (vilket jag återkommer till i nästa kapitel). Ytterligare några säger sig vilja eller ha planer på att börja studera. Därutöver finns ett antal som tidigt valt andra yrkesbanor inom t.ex. kultursfären. Dessa anger att deras mentorer haft stor eller helt avgörande påverkan på att de vågat ta steget. Andra har kanske aldrig övervägt högre studier utan har jobb som t.ex. hantverkare, resurspersonal på skolor eller lastbilschaufförer. Det går ju inte att förutsäga vad som väcks i ett barn som blir sett och tas på allvar:

Jag var 12 år och det började med att jag inte hade så många vänner, kände mig utanför och annorlunda. Har ett minne av en gemensam träff i Folkets Park. Hon hette Jessica och hade konstiga kläder. Det kändes jättebra och hon blev min vän. Hon mötte mig på en jättefin nivå. Att få känna sig som ett barn hela tiden. Bakade, sydde kläder hon lärde mig sy, vi promenerade. Vi ritade också en del, konstnärligt skapande. Vi var fr a hemma hos mig eller ute på stan. Minns inte om vi var hemma hos henne. Visste inte att hon var student. Vi utnyttjade hela tiden och har träffats någon gång efter det. Ledsen när det var slut. Det gav mig mycket, gick i sexan, ny klass jätte-nervös - lugnade och peppade. Jag är nu 27 år och har en lillasyster på 12, så jag känner igen hur det var. I dag är jag tatuerare. Hon peppade mitt konstnärliga sinne. Skulle gärna vara mentor om tiden finns. Jag är tacksam för tiden jag fick. Prata om att man är bra som man är. Vi pratade mycket om sex och kärlek - när inte mamma var med. Respekt viktigt. Hon pushade aldrig, jag blev bekväm - hon tog mig på allvar.

De f.d. mentorsbarnens berättelser rymmer en bred spännvidd när det gäller minnet av den egna barndomen. Synen på sig själv som barn varierar också. Någon minns sig själv som någon som "säkert hade ett antal bokstavskombinationer och som ville göra saker hela hela tiden"29. Andra minns sig själva som mycket tillbakadragna. En mentor kan alltså i det

${ }^{29}$ Citat från ett fokusgruppsamtal. 
ena fallet vara "ett verktyg" för barnets aktivitetslusta eller, som i exemplet ovan, någon som tillhandahåller små fickor av verklighetsflykt. I det andra fallet kan mentorn vara en vuxen som spräcker bubblan och frigör barnet. I båda fallen finns de kvar i minnet hos de barn som nu är vuxna.

Bland berättelserna sticker olika lärdomar och färdigheter fram. De viktigaste är kopplade till språkutveckling - att prata svenska, att våga och kunna uttrycka sig på svenska blir något annat när någon faktiskt lyssnar och är intresserad av vad du har att säga. Att behärska vardagsspråket öppnar upp möjligheter och blir därmed frigörande. Denna process lyser även fram i de f.d. mentorernas berättelser, främst i beskrivningarna av hur kontakten mellan barnet utvecklades över tid. Låt oss nu går över till mentorernas berättelser och hur de svarar mot verksamhetens syften och målsättningar.

\section{Utfall i förhållande till mentorernas deltagande på in- dividnivå}

Låt oss påminna om verksamhetens syften som är formulerade på individnivå. Mentorn:

- Ska få möjlighet att vara en vuxen förebild i en nära relation med ett barn.

- Ska få en inblick i ett barns liv och härigenom ökad kunskap, förståelse och empati för människor olika villkor.

- Ska få ett komplement till sin universitetsutbildning, ”kunskaper man inte kan läsa sig till”.

Det går att påstå att de tre syftena hänger ihop, till och med kompletterar varandra. Att så är fallet framkommer när jag tar del av mentorernas berättelser. I svar finns alla tre inlindade i varandra. Här några exempel på detta:

Vi pratade samtidigt som vi gjorde saker. Vi var aldrig hemma. Relationen blev bättre hela tiden. Barnet var duktig, jag lärde mig mycket av henne. Det blev ett utbyte. Vi har inte träffats efteråt. Jag ville visa hur livet kunde vara när man studerar. Presentera en students livsstil. Barnet hade redan tankar om framtiden. 
Det som började med lek och mys och "storasyster-häng” och slutade med lugna kvällar utan resten av familjen och alla syskon. Det blev också en veckas sportlov på landet och med egen säng i gästrummet. Jag lärde mig otroligt mycket - framförallt om en liten flickas behov, intressen och personlighet, men också om andra uppväxtvillkor, om det segregerade Malmö på ett sätt som inte går att läsa sig till och om hur en kväll i soffan med en bok kan vara det en liten flicka har längtat allra mest efter. Jag hoppas att det lärde henne något också, eller åtminstone att det gav henne glädje och ro just då.

Jag minns att Inez var lite blyg och att jag ibland hade svårt att hitta på saker med henne, men vi hade alltid roligt tillsammans och jag fick lära mig hur det var att vara en ung flicka. Jag hämtade henne oftast i skolan, och så gick vi och fikade, eller badade, ibland var vi hemma hos mig och bakade och någon gång åkte vi skridskor. Men flest gånger var vi nog på Aquakul och jag minns att hon frågade mig om jag hade baddräkt. När jag svarade att jag hade bikini så sa hon ”ja, du är ju vuxen”. Jag minns att jag tyckte det var lite roligt, det är klart jag var vuxen, jag var 23 år, men jag såg mig inte som en vuxen. Men det var roligt att få se sig själv ur ett barns perspektiv.

En annan gång frågade hon mig när jag fick min första mobiltelefon. Jag svarade att jag köpte min första själv när jag var 17 år, mobiler fanns inte ens när jag var 9 år. Och hon berättade att hennes pappa tyckte att 13 år var en lämplig ålder (det tyckte ju inte hon, som ville ha en genast).

Jag bodde i Helsingborg vid den tiden och vid ett tillfälle skulle han få följa med mig hem. Vi skulle åka tåg till Helsingborg och på centralen så frågar han om Helsingborg ligger i ett annat land än Malmö. Under vår mentorsperiod så möttes jag av många perspektiv likt detta med landet Helsingborg. Hur olika stora våra världar kan vara och vad dem påverkar oss.

De fyra citaten visar att rollen som förebild blir möjlig och finner näring i upptäckterna och förståelsen av barnet. Rollen som förebild och förståelsen av barnet och de verklighet barnet lever i och de 
drömmar de bär med sig ger kunskaper och insikter som en formell utbildning svårligen kan ge. "Kunskaper man inte kan läsa sig till" får, som jag tolkar det, i vissa fall en djupare innebörd. Kunskaperna och insikterna handlar även om att förstå sig själv som människa.

Något som framgår tydligt i flertalet av mentorernas berättelser är familjens betydelse. Till skillnad mot i mentorsbarnens berättelser, blir familjen högst närvarande. Flera av de kunskaper och insikter som mentorerna inhämtar kommer i mötet- och samvaron med familjen:

Jag var mentor år 2003/04 till W som bodde i X. Vi har kontakt fortfarande och träffas regelbundet. Idag är vi som systrar hon är 23 år och jag är 38 år. Hon bor i Uppsala och får i år sin civilingenjörsexamen i teknisk fysik. Jag är så stolt! Jag bor i Stockholm och har tre barn. Ibland kommer W till oss och gör god mat och spelar spel med barnen. Jag har även kontakt med Ws familj i Malmö och vi hörs alltid vid högtider som jul och nyår, eller ses när jag är på besök i stan. Dom blev som en andra familj för mig under min tid i Malmö. Jag ville dela med mig till er vår historia, både jag och $\mathrm{W}$ är fantastisk tacksamma för att vi träffades genom Näktergalen!

Jag blev mentor åt en pojke i lågstadiet ht 2003. Jag minns första mötet i Folkets park. Han kom med sin mamma och hade med sig en blomma till mig. Jag och M hittade rätt redan där direkt i parken. Jag blev varmt mottagen av hans familj, mamma och syster och var från första stund en av dem. De är sådana den familjen är, varma och välkomnande. Vi hittade på massa roliga saker tillsammans, jag och M eller jag och hela hans familj. Ibland saker av lite enklare sort. Vi spelade ex mycket fotboll. Och ibland gjorde vi något extra som att gå på bio eller åka skridskor.

Jag har kontakt med mitt mentorsbarns familj än idag. Jag träffade hans mamma bara för ett knappt år sedan. De gör mig väldigt glad att vi än idag har kontakt. M har betytt mycket för mig genom åren. Barn har så mycket kloka tankar om livet. Jag uppskattar verkligen hans familjs värme och gemenskap. Jag har alltid känt mig som en del av 
deras sammanhang sen den där dagen i Folketspark. De var ingenting jag förväntade mig. Jag vet att jag spelat roll i denna lilla mannens liv. De har jag och hans mamma pratat om många gånger. Jag gav honom lite tid och perspektiv och fyllde på med färg i hans liv, men han och hans familj gjorde exakt samma för mig. Än idag ligger hans foto från tredje klass i min plånbok.

Som exemplen ovan visar vävs de tre individrelaterade syftena samman. Det första syftet uppfylls av det andra och tillsammans ger de två de insikter som uppfyller det tredje syftet. Det innebär, vilket också citaten visar, att utdelningen i form av glädje, självkänsla och värdefulla insikter är stark. Även så flera år efter mentorskapet. Det innebär också, att om inte det andra syftet uppfylls, uppfylls inte det första och hotar uppfyllelsen av det tredje syftet. Ett par berättelser beskriver mentorsuppdraget som tungt. Anledningen som anges att de inte kände att de nådde fram till barnet. Några utrycker också att de kände en osäkerhet över om det gick bra eller inte. En känsla som kan hänga kvar långt i efterhand. Vid ett fokusgruppsamtal fick de f.d. mentorerna frågan om vad som var det bästa som hände under mentorsperioden. Samtliga svarade att det var när de kände att de "connectade" med barnet - att de var accepterade:

"Vi satt på bio och helt plötsligt lutade hon sitt huvud mot min arm.

Då förstod jag."

Ur den tillit byggd på ömsesidig respekt som skapats utvecklas både barn och mentor. För mentorn innebär det möjligheten att komma nära barnet och lära om barnets värld. Det innebär också insikter om sig själv som är värdefulla:

Jag minns det än idag min tid som mentor. Jag tyckte det var givande och jag fick bra kontakt med hela familjen. Jag fick insyn i en familjs liv som kantades av en osäker bostadssituation och allt vad det innebär. Men jag träffade även föräldrar som ville sina barn det bästa. Jag fick lära mig att samtala med barn, omvärldsbevakning, och erfarenhet av ledarskap. 
Om du tänker dig att jobba med människor i framtiden, barn sannerligen, då kan jag varmt rekommendera det (att vara mentor) därför att man lär sig saker som det bara går att lära sig genom erfarenhet. Jag förstod mycket, mycket mer, det gav mig verktyg som jag använder än i dag i min undervisning som jag fortsätter att vässa på. Herre Gud oj, nu fattar jag grejen liksom. Man håller nostalgin stången - min barndom var ett ideal - utan får ett annat perspektiv genom en relation med en annan människa. Får ta ett ansvar, en ledar-roll, se till att saker och ting händer och få lära sig väldigt väldigt mycket. Till exempel, en hemsk sak hände barnet, men han reagerade inte alls som jag skulle ha gjort, det var en jättestor grej för mej.

Genomgående lyfter mentorerna, direkt eller indirekt, olika lärdomar de gjort. Dessa går från att få en förståelse för de begränsningar - såväl personliga som sociala - som hindrar mentorn från att nå fram till barnet som försvårar eller i värsta fall omöjliggör ett fungerande mentorskap. Insikter om hur svårt det kan vara att vara barn samt djupet och vidden det åtagande som krävs för att kunna ge barnet glädje, självinsikt och framtidstro, kan vara tunga att bära. På motsvarande sätt förefaller lärdomarna från fungerande mentorskap vara lätta att bära. Som i de två citaten ovan, blir lärdomarna till verktyg för den egna utvecklingen. Effekten skiljer sig alltså mellan utfallen på individnivå mellan mentorsbarn och mentor, mellan barnet och den unga vuxna. För barnet utgör lärdomarna och självinsikterna direkta förutsättningar för att utvecklas. 


\section{MÅLSÄTTNINGAR PÅ POLICYNIVÅ}

I föregående kapitel framgick att Näktergalen mentorsverksamhet uppfyllt och uppfyller de syften på individnivå som sattes upp vid verksamhetens inledning för 23 år sedan. Tre direkta avvikelser förändrar inte den saken. Ingen verksamhet som involverar människor är vattentät. Där det av sociala och personliga skäl varit möjligt fungerar verksamheten i enlighet med sitt syfte. Utbildning, handledning och stödinsatser för att säkerställa detta har utvecklats genom åren.

Genom åren har Näktergalen styrts av olika uppsättningar av syften och målsättningar som följt på varandra. Dessa har varit de samma i sak. Det som har förändrats är uppdragsgivarnas perspektiv på verksamheten. Från att rikta sig mot själva verksamheten till att övergå till vad Näktergalen mentorsverksamhet ska bidra med för att uppfylla uppdragsgivarnas respektive policys för sin verksamhet. Det är de, vid tiden för undersökningen, aktuella målsättningarna som kommer att diskuteras här. Låt mig påminna om hur dessa formulerats:

- Bidra till breddad rekrytering och inkludering vid Malmö universitet.

- Bidra till ömsesidigt utbyte och integration i Malmö stad.

- Bidra till skolelevers och universitetsstudenters utveckling och lärande.

Ur intervjuerna framgår att 15 av de 36 före detta mentorsbarnen studerar eller har studerat på universitet. Som en intressant jämförelse, utan några som helst vetenskapliga eller statistiska anspråk, kan sägas att för gruppen Malmöbor födda 1993 - 1999 vilka gått i skolan i staden hade ungefär 
31\% läst eller läste vid universitet fram t.o.m. år 2017. ${ }^{30}$ Samma statistiska underlag visar att Malmö universitet/högskola är det vanligaste valet vid högre studier för Malmöbor. ${ }^{31}$ Det finns således indikationer på att undersökningens grupp av informanter ligger väl i jämnhöjd med genomsnittet när det gäller universitetsstudier.

Ett ömsesidigt utbyte och integration i Malmö stad är och har från början varit en av Näktergalens grundpelare. Hela verksamheten bygger på ömsesidighet och aktivitet och att hela staden öppnas för barnet. Berättelserna ger många exempel på ett ömsesidigt lärande mellan barn och mentorer. Detta ömsesidiga lärande tycks utveckla deltagarnas självförståelse. För mentorerna sker detta i hög grad i stunden eller genom handledning eller författandet av månadsrapporterna. För barnen sker det oftast retrospektivt, ibland i intervjuerna. De f.d. mentorsbarnens berättelser rymmer i flera fall funderingar över hur de själva reagerade och varför de reagerade på detta sätt.

En annan del av deltagarnas berättelser som rymmer analys och eftertanke är familjen och den sociala situation barnet befann sig i. Mentorernas möten med familjesituationer, som i flera fall låg fjärran från den egna uppväxtens, intar viktiga passager i deras berättelser. Insikten om att de faktiskt har fått förtroendet att vara mentorer åt en dittills okänd familjs barn sjunker in. Välkomnandet och förtroendet från familjen kan å ena sidan vara en positiv boost, men å andra sidan kan den vara hämmande. Avgörande är om familjens förväntningar harmonierar med mentors väl avgränsade uppdrag. I några berättelser framgår att familjens behov av stöd överskuggar det bidrag som ett mentorsuppdrag kan ge. I andra framgår att barnets vårdnadshavare och syskon var mycket aktiva för att skapa goda förutsättningar för mentorsarbetet. Utbytet gällde inte bara barnet, utan snarare hela familjen. I ytterligare några berättelser där föräldrarnas kamp för ett anständigt liv för familjen gör att barnet genom mentorn får en unik chans att få en vuxen alldeles för sig själv att prata med och upptäcka saker med. Sådant som långa eller dubbla arbetspass och många syskon hindrar.

\footnotetext{
${ }^{30}$ Statistik hämtad från SCB:s LISA-databas.

${ }^{31}$ SCB:s LISA-databas. Underlag gäller Malmöbor födda 1993 - 1999 vilka gått i skolan i staden som läst eller läste vid universitet år 2017.
} 
Mentorsverksamheten bidrag till utbyte och integration går åt båda hållen och kan vara vidare och djupare än vad som anges i målsättningen. Här finns goda förutsättningar för en direkt och samtidigt bestående påverkan i positiv riktning för alla inblandade. Sådana goda förutsättningar uppstår inte av sig självt. Nyfikenhet är en viktig komponent. Utan den kommer svårligen den vuxne och barnet samman. Det för hela Näktergalen mentorsverksamhet avgörande fundamentet och som också i mina ögon är dess signum är den alltid närvarande respekten. Hela verksamheten genomsyras av respekt som gör att den också möts av intresse och nyfikenhet från dem som kommer i kontakt med den: respekt för barnen, för skolorna, för föräldrar och för studenterna/mentorerna. Att lägga tyngdpunkten på att barnet ska bli lyssnat på, inte att de ska lära sig några av vuxna bestämda kunskaper. Att inta barnets perspektiv, vad vill barnet prata om, vad vill barnet veta, utforska och pröva. Att lita på de studenter som blir mentorer, ge dem möjligheter att upptäcka och bilda sig en egen uppfattning om barnet och mentorskapet, men alltid finnas där som stöd.

\section{Slutsatser}

Låt oss påminna om undersökningens syfte; att förstå och diskutera om, och i så fall, hur Näktergalen mentorsverksamhet i sin kärnverksamhet möter de uppsatta målen ur både ett deltagar- och verksamhetsperspektiv. Jag anser att detta syfte uppfyllts och att det med stöd av undersökningens insamlade röster och dokumentation samt min analys av verksamheten går det att dra följande slutsatser:

- Ur ett deltagarperspektiv kan konstateras att Näktergalen mentorsverksamhet genom åren uppfyllt uppsatta syften och mål, både på individ- och policynivå.

- Ur ett verksamhetsperspektiv går det likaledes att konstatera att uppsatta syften och mål uppfylls, både på individ- och policynivå.

Dessa slutsatser dras trots att berättelserna rymmer ett fåtal avvikelser, 5 av 63. Ingen verksamhet som i så hög grad som Näktergalen mentorsverksamhet bygger på- och utförs av människor kan vara utan avvikelser.

Vad kan då förklara verksamhetens goda resultat? Svaret går att finna hur 
verksamheten är organiserad:

- Mentorsverksamheten präglas av struktur och tydlighet, vilket är en förutsättning för att hålla en hög kvalité på ett mentorsprograms nyckelelement; rekrytering, urval, intervjuer och kontroll av sökande samt utbildning, stöd och handledning. Dessa nyckelelement har avgörande betydelse för att goda relationer mellanmentorer och barn ska utvecklas.

- Näktergalen mentorsverksamhet uppvisar alla element som definierar en lärande organisation. ${ }^{32}$ Verksamheten är välstrukturerad genom att den är väl utprövad och trygg i förändringar. Expansioner av olika slag hanteras på samma trygga sätt som nedskärningar. Verksamheten anpassas till bemanning. Sannolikt speglar antalet mentorspar under en verksamhetsperiod en optimering av tillgängliga personella och ekonomiska resurser.

- Näktergalen mentorsverksamhet arbetar kontinuerligt med att säkerställa att de uppfyller sina syften och uppsatta mål. Arbetet mot att säkerställa ett positivt utfall för vart och ett av mentorsparen har pågått från starten och pågår fortfarande.

- Respekt och nyfikenhet

\section{Några reflektioner kring undersökningen och förslag till vidare forskning}

Den undersökning som ligger till grund för denna rapport har redovisats under rubriken "Metod och material”. Där framkommer att det förelegat ett antal begränsningar för denna undersökning. Dessa har resulterat i att ett antal avgränsningar fått göras. De viktigaste är dels att undersökningen är retrospektiv och dels att den fokuserar på verksamhetens grunduppdrag sedan starten och därmed inte granskar den expansion både geografiskt och i fråga om målgrupper som Näktergalen Mentorsverksamhet upplevt och alltjämt upplever. Utifrån det utrymme som dessa avgränsningar gett

\footnotetext{
${ }^{32}$ Definitioner av en lärande organisation (1.) en organisation som kontinuerligt lär av sina erfarenheter i syfte att lösa sina uppgifter på ett bättre sätt. NE; https://www.ne.se/uppslagsverk/encyklopedi/1\%C3\%A5ng/1\%C3\%A4rande-organisation.; (2.) "Begreppet lärande organisation betonar vikten av att individer, grupper och hela organisationer ständigt lär samt utvecklar och förnyar sig”. Bruzelius, L, H \& Skärvad, P-H (1974/2011) Integrerad organisationslära; Studentlitteratur, Lund, s. 257.
} 
har jag valt att lägg stor vikt vid ansvariga och deltagares berättelser om sina erfarenheter från verksamheten och eventuella konsekvenser av denna verksamhet. Jag anser att resultatet varit givande, så till vida att det öppnat upp för en djupare förståelse av verksamheten, dess fundament och dess vardag samt inte minst dess nytta, likväl som dess begränsningar. Här visar sig respektens, nyfikenhetens och de tydliga strukturernas nödvändighet för att skapa goda möten mellan människor.

Vad missar då min design och materialinsamlingsmetod förutom de som är givna av dess ramar? Det är svårt att säga, det känns mer att det handlar om att andra materialinsamlingsmetoder skulle ge andra resultat och därmed andra förståelser. Att bara utgå från dokument hade givit en annan, kanske mer fragmentarisk, bild av verksamheten. En design som bygger på djupintervjuer med ett mindre antal informanter hade kunna fungera, men med risk att tappa mångfalden. I stället kan vi konstatera att avgränsningarna har medfört att en rad för forskning intressanta frågor lämnas obesvarade, liksom att ett omfattande empiriskt material i form av skriftliga och digitala rapporter av olika slag inte kunnat granskas inom undersökningens ram. Näktergalens utvidgningar av kärnverksamheten, både nationellt och internationellt, samt mot nya målgrupper utgör ett obeforskat forskningsområde. Denna rapport anlägger inte något/några uttalade teoretiska perspektiv eller i sig haft en teoretiserande ambition, vilket ger fritt utrymme för nya tolkningar. Det viktiga är att det forskas vidare om Näktergalen mentorsverksamhet. Här finns mycket att lära och inte minst att förstå.

Avslutningsvis måste poängteras att denna undersökning har genomgående varit inriktad mot verksamheten och hur den upplevts och varit organiserad, inte på ledning eller vem som gjort vad och i vilken utsträckning. Detta får bl.a. till följd att verksamhetsansvarig, sedan starten och alltjämt, hamnat i skymundan. Framtida forskning har således att addera ett ledarskapsperspektiv vid studier av Näktergalen mentorsverksamhet.

Lars Lagergren 


\section{Litteratur}

Backe-Hansen, Elisabeth, Seeberg, Marie-Louise, Solberg,Anne, Bakketeig, Elsiv \& Patras Joshua (2011) Gjensidig trivsel, glede og læring. Evaluering av mentorordningen "Nattergalen"; NOVA, 2011, Rapport 26/11

Bandura, Albert (1977). Self-efficacy: Toward a unifying theory of behavioral change. Psycho-logical Review, 84, 191-215.

Bandura, Albert (1986). Social foundations of thought and action: A social cognitive theory. Englewoods Cliffs, NJ: Prentice Hall.

Bruzelius, L, H \& Skärvad, P-H (1974/2011) Integrerad organisationslära; Studentlitteratur, Lund.

Du Bois, David, Portillo, Nelson, Rhodes, Jean E, Silverthorn, Naida \& Valentine, Jefferey C (2011) How Effective Are Mentoring Programs for youth? A Systematic Assessment of the Evidence; Psychological Science in the Public Interest; 12(2) 57-91

Lagergren, Lars \& Book, Karin (2019) Projektifiering - Fokus idrott och integration Ur: Ur: Book, K m.fl. (red.) Sport management II - Den svenska idrottens styrning; SISU Förlag, Stockholm

Nationalencyklopedin,https://www.ne.se/uppslagsverk/encyklopedi/l\%C3\%A5ng/l\%C3\%A4rande-organisation.;

Nilsson, Henrik (2013) Tre år med Näktergalsprojektet $i$ Växjö. Växjö:Linnéuniversitetet

Rubenstein Reich, Lena (2001) Mentorsprojektet Näktergalen. Mötet mellan skolbarn och högskolestudenter; Malmö Högskola, Lärarutbildningen, Regionalt utvecklingscentrum; Rapporter om utbildning 4/2001, Malmö.

Salonen, Tapio, Grander, Martin \& Rasmusson, Markus, (2019) Segregation och segmentering i Malmö: Stadskontoret, Malmö Stad

Sild Lönroth, Carina (2007) Näktergalen - en knuff framåt; Rapporter om utbildning; Lärarutbildningen, Malmö högskola, 2/2007

Stigendal, Mikael (1997) FOSIE - Sociala värden i olika sociala världar; Delrapport 3 Levnadsundersökningen; Malmö hus museer, Malmö.

Verksamhetsberättelser och bokslut för åren 2009/10 till och med 2018/19, Näktergalen mentorsverksamhet

Dokument:

Beslut om tilldelning av medel (2017-06-27) Malmö högskola, Fakultetens för lärande och samhälle, Dnr; STUD 3.5.3-2017/1102

Johnsson, Christina (2017-11-05) Utlysning: Medel för förstudie om forskning om Näktergalen; Fakultetens för Lärande och Samhälle, Malmö högskola. 


\section{Bilaga 1: Spridning av Näktergalen mentorsverksam- het}

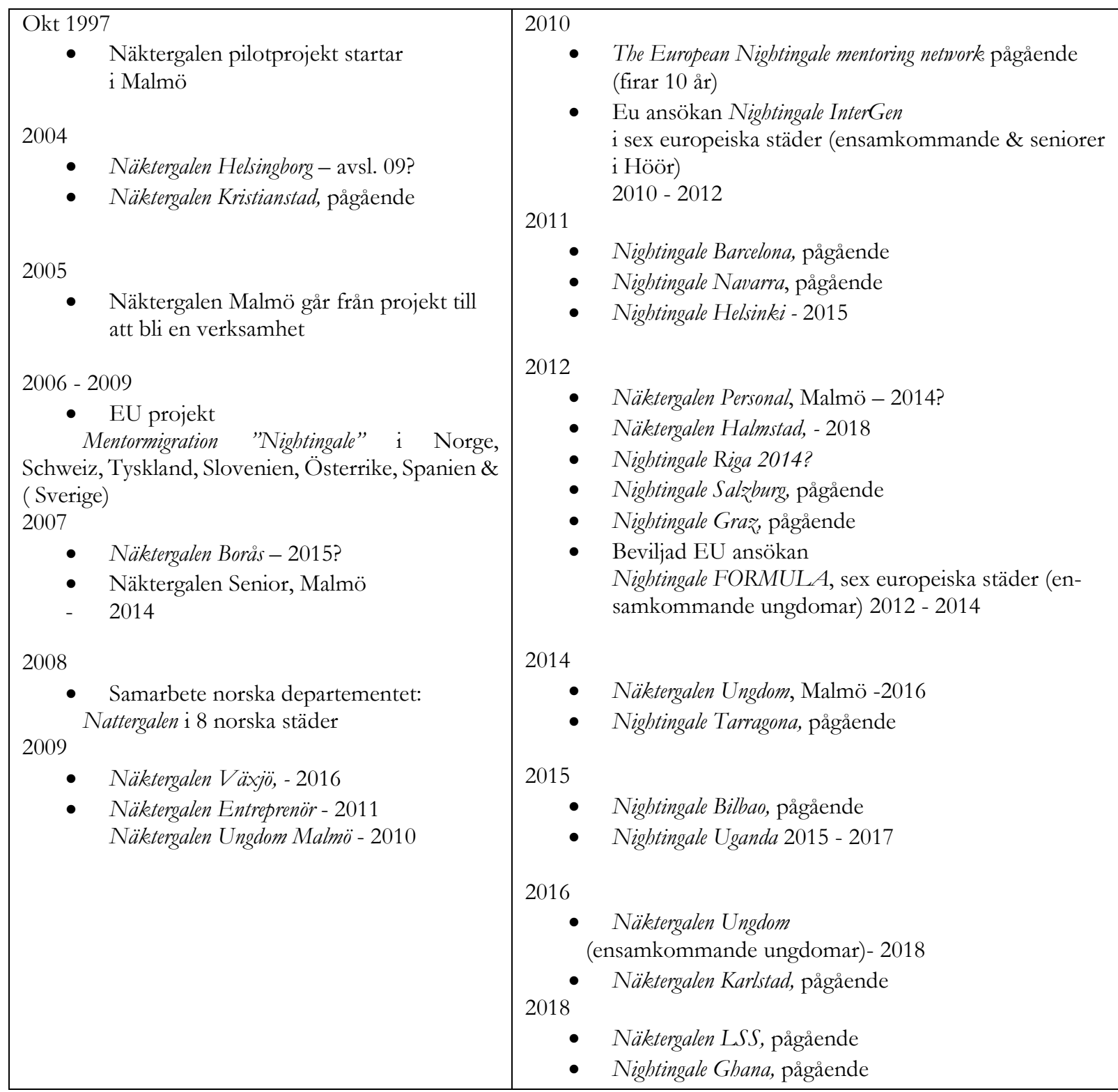

